\title{
Grundtvig as a Danish Contribution to World Culture
}

\author{
By Flemming Lundgreen-Nielsen
}

The notion that Grundtvig should have made a contribution to world culture perhaps sounds rather strange to a Dane. We have grown up with his patriotic songs and historical ballads such as "Come hither, little girls", "The sun is up" and "Much higher mountains throughout the earth". Regardless of one's personal attitude to Christianity and the established Church, Danish religious festivals would be unthinkable without Grundtvig's hymns and spiritual songs as background music, especially "Like the roses in full bloom", "Lovely is the clear blue night", "The Christmas bells are ringing now", "O welcome again, God's angels small", "Now shines the sun in all its splendour", "The blessed day" and "The leaves are fading ev'rywhere". Grundtvig has transposed Christianity into Danish with his strange ability to choose suggestive words that are not really descriptive in a naturalistic sense but somehow enable readers or singers to put their own experiences into the words each individual can relate to them personally and intimately.

He has painted Scandinavia's scenery in such a way that it poetically supplants the historical Jewish version: Christmas spells wintertime with "ringing frost", the churchgoer's encounter with the Christmas angels takes place "In the open air, on the path that leads to church/In the snow when midnight strikes", Easter becomes a stroll through a Danish churchyard where the soil "Awakens from its hibernation/In the mildness of the spring " clad in a "pale green mantle". The Resurrection is praised with an image of flowering for the benefit of mankind, "Like flowers in full bloom/Like bursting leaf-buds, growing corn" and Whitsun is the time of lilies, brilliant sunshine, the song of nightingales and warm breezes in the foliage. Even in "The Land of the Living" (1824), one of Grundtvig's most grandiose poems, one senses a Baltic or Danish coastal landscape with green woods and reeds growing all the way down to a shoreline where the sea is as smooth as a mirror - in other words, Grundtvig's picture of Denmark is the same as that outlined a few years earlier by the greatest poet of Danish Romanticism, Adam Oehlenschläger, in "There is a lovely land", later adopted as Denmark's national anthem, and by Grundtvig himself in the famous poem he wrote in his youth "The hill by the sea at Egeløkke" (on the island of Langeland, where he was a tutor at the manor house). 
Grundtvig's landscapes are always what he chose to call "transfigured", or illuminated in the sense that their true meaning lies in a religious sphere. But they are so unmistakably Danish and Nordic that in the places where he tries to write with historical accuracy about events from the Old or the New Testament it seems both alienating and exotic. The passionate nervousness and heated struggle between religions and the fanaticism that flows into our living-rooms via television nowadays has no dominating place in Grundtvig's representation. He never travelled any further south than Exeter in southwest England and thus knew neither Southern Europe nor the Middle East from personal experience. In a Christmas hymn from $1846,{ }^{1}$ he almost reproaches the Holy Land for not having Christmas weather like Denmark's, observing that the nights are not as long in the Middle East as they are in Denmark at Christmastide, that there are no snowstorms and no ice to slip on - although chilly winds do blow across their fields, just as in an early Danish spring.

To a Dane, Grundtvig's activities appear to be so wholly bound up with Denmark and the Danish language that it seems only natural that he should have written the most popular song about his mother tongue, "This heavenly sound, our mother's name" (1838). An examination of the original version, which has 20 verses, reveals that the first seven are concerned first and foremost with the mother tongue which everyone has. Grundtvig understands the term and the very concept quite literally as the language spoken by a mother, by a woman. In 1838 he was immersed in his campaign for a Danish Folk High School as a counterbalancing influence against what he regarded as the strictly Latin University of Copenhagen. Women, who had no access to the university and learned no Latin, were regarded by Grundtvig as linguistically "untainted" and a mother's voice was thus "... the lullaby/That we like best of all« and this is why the language sounded "loveliest in a woman's mouth". However, the idea of a mother tongue being an important part of the identity of a nation and of a people did not really originate from Grundtvig but from the writings of the German philosopher J.G. Herder during the second half of the eighteenth century and subsequently spread more widely by the real founder of German nationalism, the Romantic philosopher J.G.Fichte in the course of his lectures in French-occupied Berlin in 1807-08 on the theme of the German people's mission in European history, published in 1808 as Reden an die deutsche Nation (Addresses to the German Nation). 
It is remarkable that tradition, that is to say The Folk High School Song Book (1894 ff.), for example, has ousted twelve of the very stanzas in Grundtvig's poem that give a detailed characterization - in a compellingly affectionate tone - of the Danish language as the special form of expression used particularly by girls, daughters and mothers. This is conveyed through various repetitions of the same theme, because Grundtvig improvises like a jazz musician. If you read them to yourself the stanzas may seem redundant and the train of thought blurred, but the mere process of reading them aloud makes them flow almost ecstatically. Their appeal is not to the intellect but, like hymns in church, more of an attempt to confirm a belief. What counts is the innocence and purity of the language. Grundtvig's contention is that, in the same way that Vidrik Verlandsøn (in the Danish ballad about King Didrik and his giants) ${ }^{2}$ kills the Long-legged Giant, the girl's song will overcome and expel all ugly - even criminal - foreign words from the Danish language.

\section{The difficulties in exporting Grundtvig}

Although Grundtvig is a very special case in Danish literature - as are the two other outstanding writers of Denmark's so-called Golden Age, Søren Kierkegaard and Hans Christian Andersen - from a historical viewpoint he has much in common with the rest of European history's culture and literature, which means there should be a possibility of communicating his ideas beyond Denmark's borders.

Grundtvig is not - at least not yet - as well known outside Denmark and Scandinavia as Kierkegaard and Andersen. There may be several reasons for this.

To start with, Grundtvig's literary works are predominantly lyrical, and lyricism is difficult to translate into another language. Both Kierkegaard's and Andersen's prose also undeniably have finer points that are easily lost when crossing the bridge from one language to another, but they are still easier to retain than in lyrical writing, where rhyme, rhythm and euphony are likely to fade or disappear entirely.

Another reason is that both foreigners and Danes suffer from the peculiar external form of Grundtvig's works. As a writer, he was not the type of arch-Romanticist who let himself be inspired to pluck forth ideas and fantasies from an inexhaustible inner source. Much of his work, in 
fact probably most of it, was written in reaction to events or circumstances in his surroundings. From his debut in 1804 - all of three letters to the editor of the Copenhagen newspaper Politivennen (The Friend of Law and Order) about a schoolteacher's post on the island of Falster that had remained unfilled for ten years - his writing was a continual process of interaction with everyday life. To put it a little crudely, his æuvre was one long reader's letter rather than a whole series of works of art. Grundtvig liked to develop his ideas tentatively, hesitantly and fragmentarily, confronting local phenomena whose background foreigners cannot be expected to know and therefore need to have explained.

The poem he wrote in 1872 to mark his departure from this world describes his imminent voyage across the tempestuous sea of death towards the land of the living. It retains a dignified tone, using mythological and Christian metaphors. But an unfinished very last poem inscribed afterwards in the same journal seems to be concerned with his annoyance at the demolition of Copenhagen's Nørrevold (North Rampart), the Danish capital's fortification on the landward side, in other words always reverting from high pathos to the local Copenhagen scene. ${ }^{3}$

Apart from a long series of lyrical texts and some theological and historical textbooks, Grundtvig wrote no real major work or works in which his whole nature and world of ideas can be pinpointed briefly and concisely. He has become a Danish classic without having left a single clearly classic book behind him. Once again, there are several reasons for this.

First, Grundtvig's working method was, as he said, "to write his way to clarity". In his diary, the entry for 9 September 1806, reads: "Quite frankly, I never have a result in my mind at the outset of my investigations but permit them to develop on their own as I discuss my ideas." Grundtvig regarded thinking as an action inextricably bound up with writing. The wealth of his unpublished manuscripts - more than 500 packages in the Grundtvig archive in the Manuscript Department of the Royal Library in Copenhagen alone - bear witness to this. Compared with his manuscripts, which are nearly always preliminary drafts, hardly ever manuscripts ready for printing, his published texts are concentrated. But as anyone knows who has tried to read a lengthy text by Grundtvig, concentration is a relative matter. In many of his printed writings he feels there is a point in allowing his reader to follow his 
reasonings towards some result or other. In practice this can easily mean a dozen pages of argumentation prior to a reasonably clarified conclusion covering a page and a half. His two periodicals (which he wrote and published single-handed), each in four volumes, Danne-Virke (the name of the ancient defenceworks on the Dano-German border) (1816-19) and Danskeren (The Dane) (1848-51) adhered to this formula. This quibbling procedure, combined with what at times seems to be a desperate communication technique, makes Grundtvig unique in Denmark's Golden Age. Other writers - even the complicated and rambling Kierkegaard - polished their work until they achieved the desired effect.

Furthermore, in a letter to his friend and fellow-poet B.S. Ingemann of 27 November 1824, Grundtvig made the remarkable observation about himself that he could be more lucid when expressing disagreement with a given argument than when trying to indicate that he concurred:

I am the armour-bearer of the spirit, far better suited to make myself understood to enemies than to friends, able to express clearly my particular outlook, my strict and deliberate antagonism to whatever is base, self-opinionated and fatuous in our times, but only very obscurely to express my solidarity with those devoted to spirituality.

He even acknowledged the ancient "tyrannical motto oderint, dum metuant [let them hate as long as they fear] levelled at the entire bunch of self-appointed governors in the kingdom of the spirit". ${ }^{4}$

Also forming part of Grundtvig's view of human existence was that clarity - or, as he frequently expressed it in a term from the New Testament, "transfiguration " - would not be possible until the fullness of time, that is to say with the Second Coming of Christ on the Day of Judgement and the establishment of the Kingdom of God. The fullness of time is the manifestation of God's calendar and as such can neither be accelerated nor controlled. The approximate, that which is only intuitively perceived, represents the conditions of mankind and human life. Grundtvig regarded whatever was obscurely and metaphorically expressed in poetry as indicating the presence of genuine visions and feelings. In a letter to Ingemann of 4 December 1824 he describes himself as "a mixture, a fermentation that forfeits life as soon as it tries to prevail on its own". 
This is why patience is an indispensable quality in both Grundtvig himself and his reader. One might perhaps venture to suggest that Grundtvig really made no great effort to reach clarification. In his view, what every reader was obliged to live through and experience for himself should not be confined within strict categories. In practical terms, this means that his poetry is filled with ambiguous and flickering symbols, whereas his prose supplies several sighting lines which the reader himself is supposed to extend to form a complete figure. The result, however, is a series of interpreters who do not necessarily agree on what they understand. All these factors render communication of Grundtvig's thoughts difficult. Moreover, it cannot be denied that he lived for so long and wrote so much that he changed his mind about certain matters and thus began to contradict himself. This applies to his attitude to literary and political censorship, to North Schleswig and to the dialectic between the Christian and the national.

A third aspect that emerges - especially in his writings on education (1836-47) - is Grundtvig's conviction that life itself must always take priority over planning, textbooks, systems and theories. In this connection he sometimes uses metaphors related to growth, a term derived from the New Testament and also a humanistic concept. That which grows according to nature's order is for the benefit of the people and a blessing. What is truly living can be neither forced nor directly governed. Maturity, an important concept in Goethe's philosophy of life (for which Grundtvig cared little) was also a key word for Grundtvig: "Then will a plant approach its ripeness/And with its fruit delight at harvest time."

The same applies to Grundtvig's writings. The organic development of his $2 u v r e$ makes it difficult to penetrate his works and then emerge with immediately serviceable tools with which to transform his ideas into reality. The Danish scholar Hans Brix characterized the poetic structure of Grundtvig's confessional poem "The Daffodil" (1817) by the following apt comparison:

When examining a Grundtvigian work one feels like somebody in the jungle who tugs at a single tendril and instead of freeing it gradually drags out the whole primeval forest. ${ }^{5}$

Furthermore it can be a problem - also for native Danes - to understand Grundtvig's Danish. In its slightly antiquated nineteenth-century form, in which the meaning of words may be different from modern Danish, it 
can of course be interpreted with the help of such dictionaries as are available. But Grundtvig had a (bad) habit of using ordinary Danish words in his own peculiar way without drawing attention to the fact. A relatively harmless example is in his youthful lyrics, where he apparently distinguishes between 'to stare' in the sense of seeing without penetrating below the surface, and 'to see' in the sense of acquiring deeper insight. Worse, and more important is his use of the words Folkelighed and folkelig (literally 'folklikeness' and 'folklike', at first in the sense of having a national character but later expanded to embrace everything that is 'of, like and for the people'). The language of two older major writers, both regarded by Grundtvig as literary classics, has been registered: there is a five-volume dictionary of the vocabulary used by Ludvig Holberg, the father of modern Danish literature in the Age of Enlightenment, published between 1981 and 1988, and a similar (unpublished) compilation of that used by the seventeenth-century hymn-writer Thomas Kingo exists on file cards. To some degree we also have a key to Kierkegaard's world of concepts in the index volume (XV) of his Samlede Varker (Collected Works, 1936). But no Grundtvig dictionary exists, nor is one in the course of preparation; if ever published in the future it should include a list of his symbols.

Danes as well as foreigners who may wish to acquire editions of Grundtvig's writings in order to study him peacefully at home will run into yet another obstacle, namely the fact that only part of his auvre has been reprinted in recent times - though admittedly an important part. The largest edition of Grundtvig's poetry appeared in nine volumes between 1880 and 1930 on the basis of partially outdated publication policies and with very few indications of variants; the best edition of Grundtvig's writings, both verse and prose, is the ten-volume edition edited by Holger Begtrup and published between 1904 and 1909, because it predominantly contains complete texts. The last, but now finally sold-out edition, is the ten-volume selection edited by Georg Christensen and Hal Koch, published between 1940 and 1949; compared with Begtrup's, it has more texts that are abbreviated or incomplete in other respects. Finally, mention must be made of the Haandbog i N.F.S. Grundtvigs Skrifter (Handbook of N.F.S. Grundtvig's Writings) edited by Ernst Borup and Frederik Schrøder, I-III, published between 1929 and 1931, which is an excellent collection of Grundtvig's most fundamental views on matters connected with education, nationalism and the Church; however, some of the quotations from his long 
expositions have been included in such abbreviated versions that it is not always possible to understand them in their original historical context.

A few individual texts such as Nordens Mythologi (1832) and some selections, such as K.E.Bugge's two-volume work devoted to Grundtvig's tracts on education (1968), have appeared in an adequately scholarly form. But even these new publications go out of print, with the result that it can be difficult today for the ordinary book-buyer to get hold of reliable editions of Grundtvig's writings. However, between 1974 and 1988, the Århus theologians P.G. Lindhardt and Christian Thodberg produced splendid editions (independently of one another!) of hitherto unpublished sermons given by Grundtvig, a total of 16 volumes, which may serve to illustrate Grundtvig's activity as a preacher and theologian. However, the sermons were never printed in his day and were heard by relatively few people, so their influence at the time can only have been limited.

If one does not master Danish, the field of vision becomes even narrower. A small part of Grundtvig's poetry, mainly hymns, has been translated into both English and German and may be sought in anthologies of Danish poetry. His extensive prose writings, published as well as unpublished, which have played a steadily increasing role during the past fifty years of Grundtvig research, are accessible only in very small selections in languages other than Danish; there are a few more in German than in English, a circumstance which - in view of the fact that English is a second language for many nations - is also detrimental to the spreading of a knowledge of Grundtvig internationally. Research, too, is broadly speaking a closed country to those who are unfamiliar with Danish. Older Grundtvig research carried out by clergymen, theologians and folk high school teachers as well as the more academical approach that was developed after Hal Koch's Grundtvig lectures at the University of Copenhagen in 1940 (and especially after the founding of the Grundtvig Society in 1947) is published predominantly in Danish. However, some of its results have been presented in English and German surveys in major anniversary years $(1972,1983)$ and a number of other major scholarly works have summaries in either English or German, as do the articles published in the year-book Grundtvig-Studier. 


\section{Recent initiatives}

Despite the above-mentioned obstacles it would appear that during these years, more than a century after his death, Grundtvig's name is beginning to spread beyond the borders of Denmark, even though he still lags far behind Kierkegaard and Andersen. Grundtvig himself would no doubt have regarded the growing maturity of other countries and hence their willingness to accept him - with indulgence, perhaps on account of the quality for which he praised the legendary Danish king Rolf Krake (his source was the medieval historian Saxo Grammaticus): "Patience is the supreme form of courage."

Several interesting initiatives have been taken within the past decade. In connection with the University of Cologne's 600th anniversary a conference on Grundtvig was held there in 1988 that was attended by more than 200 participants, by far the majority from Germany and other German-speaking countries. Two years later, in 1990, the German organizer of the conference, Paul Röhrig, a professor of educational science, was able to note in his foreword to the book in which the contributions to the conference were published, Um des Menschen willen (For the Sake of Man), an unexpectedly wide response from the press, scholarly journals and the radio. In 1988 - more than a year before the fall of the Berlin Wall and Germany's reunification - the debate was concentrated on four points: Grundtvig's understanding of the sequence: "First a man and then a Christian «; his concept of Folkelighed in the sense of the development of qualities inherent in all peoples; his concept of nationalism; and the transfer of his ideas to practical everyday life, for example, congregational life and folk high schools. On the back cover of the book - and thus after Germany's reunification - mention was made of the importance of Grundtvig's bold ideas and radical reform proposals as a challenge to intellectual and social life in Germany. It was emphasized that Grundtvig's fundamental idea - about the formation of a national identity being impossible without free general education available to all - had become of great topical interest to the Germans. This was most enlightening for a Danish Grundtvig scholar. Grundtvig has become so firmly established in the Danish intellectual climate that it came as a surprise to have to go all the way to the Rhine to see attention being drawn to the boldness and radical nature of his thinking! 
In 1994 Norbert Vogel from the University of Tübingen, who had attended the congress, published a doctoral dissertation entitled Grundtvigs Bedeutung für die deutsche Erwachsenenbildung (Grundtvig's Importance to German Adult Education) in which he examined the period between 1810 and 1920 .

Another initiative arose in 1988 from the Centre for Grundtvig Studies at the University of Aarhus, which during the first five years of its existence, in co-operation with British scholars and churchmen and just one American professor, focused on the theme of "Grundtvig and England“. The result was the publication, just before Christmas in 1993, of Heritage and Prophecy, consisting of eighteen contributions (all in English) from this international group; to everybody's surprise the book quickly sold out and had to be reprinted.

These English-language essays on Grundtvig's universe - which consisted of extensive monographs, not just introductions as in the jubilee books from 1983 - resulted in a Grundtvig conference in Chicago in the summer of 1995 sponsored by the American LutheranEvangelical Church and attended by Danish Grundtvig scholars as well as American churchmen and university people, in all close to fifty participants; a follow-up event, also in the USA, is being planned.

For a Dane with primarily a literary, historical and academic interest in Grundtvig it has been a remarkable experience to discover that, in a foreign country with no previous knowledge of him, he can be regarded as a very up-to-date and modern thinker. The fact of his being physically dead is of no importance to those confronted with his writings for the first time. Whereas Danish Grundtvig researchers work steadily with a view to a coming book or a contribution to the next Grundtvig-Studier year-book, what do we find but the German Folk High School teacher in the shadow of Cologne Cathedral and the American clergyman from the church on a street corner in windswept Chicago saying "Yes, but what can I learn from Grundtvig that I could use at home on Monday next week? "Having a question like this thrown at one is really stimulating. Even though some of the above-mentioned participants knew a great deal about Grundtvig (and others not very much), the reaction was genuinely Grundtvigian: life and everyday experiences are more important than academic and theoretical considerations. As Grundtvig observed during the periods he spent in England, "facts are stubborn things". When he visited London during the summers of 1830 to 1832 with the aim of studying Anglo-Saxon 
and to begin with cared little for modern England, the English responded to his critical observations with a counter-question about modern Danes: "But what do you do?" Until then Grundtvig had given little thought to the matter, but this often repeated little sentence rankled in his mind for some years until he set about activating his countrymen by means of public speeches at popular meetings and from 1848 in the Rigsdag (Denmark's parliament at the time) as well as in his writings and indirectly through his pupils' folk high schools.

A fourth initiative, edited from 1985 by three Copenhagen Grundtvig scholars, Professor Theodor Jørgensen of the Institute for Systematic Theology, Professor K.E.Bugge of the Royal Danish College of Educational Studies and Flemming Lundgreen-Nielsen of the Institute for Nordic Philology, concerns a three-volume selection of Grundtvig's writings in German translation covering about 1,000 pages of text and a total of 100 pages of introductions and commentaries. One volume is devoted to poetical-cum-historical writings, one to educational and/or political matters, and one to theology. All three volumes include poetry relevant to their respective fields. The main principle is to include complete versions of the texts, or alternatively whole parts or whole chapters, not just short excerpts or heavily abridged versions taken from songbooks or hymnbooks. Everything has been translated as accurately as the differences between Danish and German permit, the poems moreover retaining the original rhythms and rhymes and with a parallel Danish text. As a German sentence - on account of the unavoidable inflectional suffixes and articles - can become as much as a third longer than the original Danish, it has not, however, been possible to retain consistently all the nuances in Grundtvig's wording. The translators and commentators consist of a score or so of collaborators with a DanoGerman background, several of them completely bilingual. They include Danish clergymen from South Schleswig (the Grundtvig Werkstatt) and university, library and ecclesiastical representatives from Denmark, other Scandinavian countries, Germany, and also a professional interpreter. All the texts have been circulated three times between the editorial office and the individual collaborators before being approved as the best possible; a fourth round (which we have not yet reached) will be to have them read by a German academic who has no knowledge of Danish to ensure that the German translation contains no Danish turns of phrase or unacceptable German. 
Until now the work has been funded by grants from the Ministry of Education, the State Football Pools and a few other large private foundations; in addition, a number of the collaborators are employed at higher seats of learning and therefore have been able to get their contributions acknowledged as part of the individual research which they are under a contractual obligation to make. The final manuscript should be ready within a year, after which money must be found to have it printed. As the greater part of the notes and introductions has been written in Danish and then translated, the editorial board plans to have the whole work published in Danish as well. If this materializes, it will be the largest selection of Grundtvig's writings to be published for almost half a century; such detailed and consistent editorial commentaries as we have compiled are unprecedented.

\section{Grundtvig's potential}

What is it then that Grundtvig has contributed to world culture and what, in the course of his increasing international fame, can he be expected to contribute in the immediate future?

Grundtvig has an incontestable reputation as a scholar of AngloSaxon, or Old English. The principal text, the epic poem Beowulf, which has survived in a single manuscript dating from the tenth century, was first published in Copenhagen accompanied by a modern, somewhat inadequate Latin translation in 1815 . So as to be able to judge this new source of Danish legendary history, Grundtvig taught himself Anglo-Saxon at lightning speed: with his eagle eye he immediately saw that the editor had not understood the poem's introduction. He thereupon extracted from the verses the story of King Scyld's funeral aboard a ship with his treasures, which have never been seen since. The correctness of his reading remains uncontested. In addition, Grundtvig identified one of the characters, Higelac, as a historically known king and contributed a number of specific improvements to the text. He himself re-created the whole poem in Danish in 1820. It was the first version to be published in a modern language (an English translation did not appear until 1837). Furthermore, in 1861 he published a philologically purified text in Anglo-Saxon.

Grundtvig was a discerning Beowulf scholar. As early as 1817 he dismissed the contention that the text was a source of Nordic heathen 
antiquity but instead called it the first attempt in Christendom to elevate secular history to an epic written in a European language. This is an accurate description. In modern editions of Beowulf - and also in research surveys - Grundtvig is fully recognized by the British for his pioneering contribution. Professor Eric Stanley spoke in 1981 of the "astonishing brilliance" of Grundtvig's Anglo-Saxon research, a statement confirmed in 1995 by another British researcher, Sidney Bradley, in Chicago. However, this international reputation is confined to a relatively narrow circle of scholars and students; probably few people in Denmark are aware of Grundtvig's contribution to Anglo-Saxon research.

Danish theologians believe that Grundtvig's theology can also make a contribution to world culture. ${ }^{6}$ It has aroused interest in Germany, both before and after reunification, and may also be pertinent in connection with Christian missionary activities in the Third World. In the 1830s Grundtvig had expressed his view of the relationship between the nationally secular and the Christian in the formula "First a man and then a Christian" in a poem that was not published until 1880 . He asserted that one can only be a human being in conjunction with one's own people, and that the path to Christendom must therefore pass through a consciousness of the folkelighed (in the sense of popular or national). By this Grundtvig meant what is made up of common language, history and present-day culture. Just as the Son of God had to become a human being and live a human life, Christendom, which is universal, must come to any nation in its native language like a heavenly guest in an earthly home. In a long poem devoted to ecclesiastical history, Christenhedens Syvstjerne (The Pleiades of Christianity), which began to appear in instalments in 1854 and was published complete in 1860 , Grundtvig describes six specific national congregations - Hebrew, Greek, Roman, Anglo-Saxon, German and Nordic - all of which in the course of history were aroused to national self-consciousness and therefore played a role in the growth of the Church. Grundtvig was naturally a Lutheran, but in this poem both the ancient Church in Rome and the Anglo-Saxon Church are regarded as necessary chapters in the history of salvation, determined by national factors, namely the characteristically inherent qualities in each nation, which Herder called Volksgeist (national spirit). This actually corresponds to present-day ecumenical theology, in which emphasis is placed on non-theological factors in individual Christian confessions in the hope of explaining and 
understanding differences and thereby strengthening a sense of community. Theologians, particularly in the Third World, have studied Grundtvig with interest because his ecumenical attitude grants their own country's non-Christian prehistory a stage in the development towards a national Christianity. This is actually how Grundtvig treated Nordic mythology from his early youth: his forefathers' belief in one chief deity, the Father of the Universe, was their premonition of Christianity (as yet unknown) and thus prepared them, without their realizing it, for the preaching of Ansgar and later missionaries.

Grundtvig's theology contrasted with what came to dominate during the nineteenth century, when the aim was to replace the local cultures of the Third World with a Western European Christianity - this was for example how missionaries in the British Empire functioned.

As a result of his writings about the language conflict in Schleswig, the Three Years' War and Denmark's defeat in 1864, Grundtvig became known for having turned Christianity into a Danish national religion and for making the continued existence of Denmark and the Danish language a prerequisite for God's accomplishment of His plan for the world. Critics of Grundtvig both at the time and today call this chauvinism.

There is nothing very surprising about the fact that a man with Grundtvig's poetic temperament and love for his country should have reacted strongly in a moment of political crisis. On 5 May 1945, when Danish newspapers were able to publish their first uncensored editions since the German Occupation in April 1940, the writing was also in a tone that later generations have found difficult to understand and accept. In connection with Grundtvig's nationalistic pathos it must therefore be emphasized that at other times his range of vision was far wider. $\mathrm{He}$ understood that the entire Christian Church consisted of God's people, possessed of a common Christian sense of solidarity, and of Christians from various individual nations. What united them was the Holy Ghost, and in this connection his interpretation of the Pentecost becomes important: the fact that individual apostles were filled with the Holy Ghost, causing them to speak "with tongues of fire", resulted in preaching about the same divine acts in different mother tongues. In his Kirkelige Oplysninger isar for lutherske Christne (Church Enlightenment, especially for Lutheran Christians), published in instalments between 1840 and 1842 and in book form in 1870 , Grundtvig states that earthly solidarity should serve the Christian spirit 
of solidarity, and that the former can in no circumstances replace Christianity. National sentiments should not become the object of a religious cultivation of faith. A sense of national togetherness can only be temporal, whereas in Grundtvig's view Christianity's validity is both temporal and eternal.

At the present, when churches based on varied confessional foundations are abused - and permit themselves to be abused - to sanction conflicts between different nations and ethnic groups (in the Balkans and Northern Ireland), openness and tolerance deriving from the idea of a common Christian Church might provide an answer. Grundtvig touched on this in his hymn "Universal is the Church of Christ ", ${ }^{7}$ which gives meticulous instruction on the matter, and of course also in his best known Whitsun hymn, "Now shines the sun...", in which he describes how, in the name of Jesus, tongues will glow among heathens as well as Jews, all tongues will be melted down in a sacrificial bowl and an eternal Halleluja will be heard.

Contrasting with Grundtvig's numerous and vehement utterances about Danish nationalism and Nordic solidarity is his international orientation - what he himself called his 'universally historical outlook'. It is worth remembering that he wrote four detailed books about the history of the world and a long European ecclesiastical history (in all close on 4,000 printed pages), but never - apart from his chronicles in verse - a history of Denmark or a Danish ecclesiastical history.

Grundtvig's most important export article is undoubtedly his folk high school concept. In Danish, the term 'high school' used to mean 'university', and in a series of publications between 1836 and 1847 he demonstrated that by 'folk high school' he meant a Danish university as opposed to the Latin-dominated University of Copenhagen. It was to be an institution where Danish citizens could learn about Danish history, language, literature and - of course - social conditions. It was to have as few restrictions and regulations as possible. Students should attend voluntarily and at their own expense. There was to be no question of syllabuses, examinations, examination certificates or academic degrees. Instruction was to be predominantly by word of mouth, textbooks were to be restricted to a bare minimum, and teachers were not to lecture but as far as possible encourage a form of dialogue. The aim of the folk high school was to cultivate education for the sake of living, not for the sake of academic titles, officialdom or higher salaries. Its form of dialogue, with emotional elements and oscillations as well as the lack of logic that 
lies in sudden impulses, was to provide a counterweight to reasoned academic discipline.

Teachers as well as students were to remain at the school, also outside tuition hours. Originally Grundtvig wanted to have attendance at a folk high school linked to the running of a nearby farm and its various forms of associated craftsmanship to enable young farmhands to keep up their working routines. Physical exercise beyond this was not included in his idea. ${ }^{8}$

The key term in the folk high school concept is spiritual interaction through the spoken word. Grundtvig visualized the absolute monarch from 1839 Christian VIII, whose queen was virtually the first real Grundtvigian - making over the illustrious old Sorø Academy south of Copenhagen for the purpose; as a branch of the University of Copenhagen it experienced difficulty in attracting students to its quiet provincial town. Grundtvig's idea was thus to set up a single, central institution, sufficiently influential to promote Danish culture and Danish social consciousness, financed and run by the State. Although the king had almost yielded to Grundtvig's (and his queen's) campaign, the project was stopped by Christian VIII's sudden death in 1848 and ousted by the politics of the following months and years: the war against the Schleswig-Holstein rebels and the question of the Constitution.

Before then the first folk high school had been opened on 7 November 1844 in Rødding. It was privately financed and extremely modest in size - merely a score or so of locally recruited pupils. Although he received several invitations, Grundtvig never visited it. It seems he continued to dream, both at the time and for the rest of his life, of the school at Sorø (the academy had been closed down in 1849). However, local folk high schools arose in various parts of the country; an annual government grant was provided already in 1851, though not confirmed by law until 1913. These schools contributed, especially after 1864, to uphold an ideal of Danish national solidarity. In practice, the folk high school idea left room for philosophies other than Grundtvig's Christian outlook, and today there are over 100 folk high schools in Denmark based on rather varied sets of values. Up to the present, however, the Danish folk high school, which has become a national jewel on a level with The Little Mermaid, is still essentially the heir to Grundtvig and his first disciples.

Precisely on account of Grundtvig's disinclination to prescribe an organizational structure for this kind of school for adults over eighteen - 
which until 1861 applied exclusively to men - it has also proved possible to introduce the concept with certain slight adjustments in cultures outside Denmark. ${ }^{9}$ Apart from Scandinavia and Germany there are folk high schools today in the USA, Japan, the Philippines, Israel, Chile, Nigeria, Ghana, India, Bangladesh, Poland and Hungary; the idea is also being examined in Russia and the Baltic countries. The principal feature of these schools, which are often set up with advice and assistance from Denmark, is the emphasis on an interplay between Christianity and everyday life, formed in accordance with - and by - the culture in question. Institutions have also arisen that are un-Grundtvigian in that they offer technical training and hold examinations. This may be due to local conditions, for example the need not just to establish a national identity in a decolonized African country but also to lay on water, build roads and bury electric cables. Nevertheless, these schools often try, in the Grundtvigian spirit, to attach more importance to strengthening pupils' consciousness of themselves and of belonging to a national and spiritual community than to merely teaching them practical skills.

In the course of a Bangladesh project financed by the Danish Ministry of Foreign Affairs (DANIDA) it was discovered that the informal style of tuition probably arouses an uneasy feeling amongst students who would find it easier to grasp the aim of purely practical training assessed in terms of examination certificates. In consideration of this, which in itself is not surprising, one is able as a Dane to see that even what is customary may be relative and then begin to wonder why Danish farmhands in the middle of the last century did not react in the same way. The answer can most likely be found in the amputation of Schleswig-Holstein in 1864. As the Danish novelist Herman Bang and other literati asserted, it represented a shock, but it also meant that the Danes, realizing that Denmark could now hardly become any smaller, felt a desire to make a real effort to create, uphold and reinforce a Danish identity and sense of belonging to a Danish mother country.

Grundtvig's repeated advocacy of nationalism would be eminently suitable for export if one merely replaced 'Danish culture' by other corresponding national designations. In the course of his long life Grundtvig undeniably experienced moments when love of his mother country and his native language caused him to express himself fervently about being Danish - the Battle of Copenhagen in 1801, the danger of the allies breaking into Denmark prior to the Peace of Kiel in 1814, the 
Three Years' War of 1848-50 and the defeat and conclusion of peace in 1864. These decisive events in Denmark's history developed in Grundtvig a faith in all things Danish as God Almighty's means of invoking a new 'golden year' for all Christianity. Strangely enough, the more his native country lost and suffered, the more optimistic did the ageing Grundtvig become with regard to its future. ${ }^{10}$

European neo-nationalism after the disappearance of the Iron Curtain and the Berlin Wall can no doubt make a modern observer sceptical about Grundtvig's concept of a nation. History, language and society as common and delimiting factors have not always proved enough to create peace and happiness the way Grundtvig and the Danes were inclined to believe in their small mono-cultural and mono-lingual state from 1864 until about 1966, when migrant workers began to pour into Denmark. The concept of national solidarity forged by Grundtvig to defend Danish culture in Schleswig could become a disturbing weapon of attack when exported.

In his often quoted poem "Folkelighed", written in August 1848, Grundtvig turned things over in his mind after the springtime revolutions in Berlin and Paris and the peaceful upheaval in Copenhagen. In the same way that his song "Moders Navn ..." is principally concerned with a mother tongue and then turns to the Danish language, the first half of "Folkelighed" is concerned with the concept of nationality and national feeling, while the second half determines the substance of Danish national feeling. Some commentators have wanted to read pre-Nazism into the poem's sixth stanza, which states that "Byrd og Blod er Folke-Grunde/lkke Luft og mindre Staal" (Birth [in the sense of descent] and blood determine people/Not air [in the sense of cant], steel even less). It does indeed resemble the Nazis' pseudo-biological nationalistic theories (and obviously becomes problematic in German translation!). However, 'birth and blood' has nothing to do with racial purity or the breeding of superhumans but refers, according to prose passages written by Grundtvig in the same year, to the brotherly and sisterly feelings people should have as a present generation towards each other, the parental respect they should display towards their predecessors and the love of children with which they should embrace their descendants: 'air and steel', rejected as the basis for a nation, must refer to barren theories of the political state (the German Reich as the heir of the Roman Empire) and to military power (Russia, perhaps also Napoleon's France). In line 7 the individual has the choice of belonging 
to a people or not: it calls for an act of will, a decision, followed up by a feeling for one's mother tongue and unconditional support of one's mother country (by which Grundtvig no doubt meant the sum of Danish history to date). The second part of the stanza usually receives less attention. It actually concerns the existence of profit-seeking native Danes who reject national solidarity. In this way they bar themselves "from the people" and virtually waste their right of citizenship. Inane materialists and cynical speculators cannot "belong", for as the poem finally declares: "Dansk er immer Kiærlighed" (Danishness is always love/charity). It may be that the wars of later years in the midst of Europe and Russia would indicate that caution should be observed before exporting Grundtvig's concept of national solidarity. Some people today may yearn for a multi-national and multi-lingual kingdom like the Dual Monarchy of old Austro-Hungary, while others believe in the expanded European Union and a larger NATO. Grundtvig's concept of national solidarity in nineteenth-century Denmark was not unique. As mentioned above, Fichte spoke in similar terms of the Germans, and other European states also held their particular role in world history in high esteem. To regard one's own particular nation as God's chosen people was a Romantic idea.

The part of Grundtvig's concept of national solidarity most suitable for export is undoubtedly his civil theology, that is to say his ideas about the organization and function of society, the place of the individual and the aim of both the individual and the community. ${ }^{\text {"It }}$ was in England that Grundtvig discovered not only freedom and its favourable effect on the everyday lives of Britons but also the present as such. ${ }^{12}$ Starting with his long philosophical introduction to his Nordens Mytologi (Handbook of Nordic Mythology) (1832) he worked his way towards a secular, contemporary form of education as a prerequisite for the individual's transition to a true Christian faith. Even before the finest means of achieving this was available - the folk high school - Grundtvig himself conducted in the heart of Copenhagen two successful experiments in creating spiritual and physical solidarity: his public lectures on European history between 1788 and 1838 given at Borch's college during the autumn of 1838 and published posthumously in 1877 under the title Mands Minde (Within Living Memory) and the foundation of an open lecture and debating society called the Danske Samfund (Danish Society) in 1839. In a speech of 14 April 1843, Grundtvig commemorated two violent April events in Denmark's history that 
miraculously restored the self-respect of the Danes and saved the country, namely the assassination of the German oppressor, Count Gert of Holstein, by the Danish nobleman Niels Ebbesen on 1 April 1340, and the Battle of Copenhagen, fought courageously against Lord Nelson on 2 April 1801. Grundtvig's point was that throughout their history the Danes have adhered to the idea that only peace is worth fighting for. $\mathrm{He}$ formulated his ideas of an ideal society - the Danish kingdom - as follows:

By making conquests, any noble nation loses far more than it gains, and by conquering the world it would actually lose itself. It can, however, within narrow confines and ignored by the world, be thoroughly happy when allowed to own the land of its fathers peacefully, express itself freely and converse in its mother tongue with both high and low, scholars as well as laymen, without causing offence to anybody, following its inclinations and the impulses of its heart in things great as well as small, at home as well as abroad.

In his last folk high school monograph, Lyk $\phi n s k n i n g ~ t i l ~ D a n m a r k$ (Congratulations to Denmark) (1847), Grundtvig considered Danish society from within: one should take care

to get one's plot of land enclosed and fenced in, get all one's worldly goods, both living and dead, marked so as to distinguish them from those of one's neighbours [...], entrench oneself henceforth without causing offence to others, yet without taking any notice of what other people might think and do, to arrange everything in one's own house and on one's own preserves according to one's own wishes, one's own ideas and one's own comfort.

The aim was peace, fairness, happiness - not glory, power, shrewdness, adroitness or fame. ${ }^{13}$

Grundtvig's aim was an everyday form of culture embodying a concept of freedom according to which each individual would voluntarily realize that he has no right to more freedom than he is prepared to grant his neighbour. Outside Denmark it is very easy to run into comprehensibility problems in this connection. At the congress in Cologne, several German participants nodded in agreement at this formula for Grundtvig's Danish social pact - oh yes, the notion that the common good should take preference over the wishes of the individual was something they knew very well from good old Prussia. It thus 
became necessary to stress the fact that in Grundtvig's case there was no question of a compulsory collective in the interests of the State. Then a quizzical gleam would appear in people's eyes: how is one supposed to coax forth a voluntary form of subjugation?

What emerges here is a historically determined difference in mentality which Grundtvig himself was perfectly aware of - and undeniably helped to exacerbate. The Germans - and especially the Prussians - had too much of the old coercively ruled Roman Empire in them. But until Grundtvig's youth, a Latin inscription on a tablet over the fortress gate in Rendsburg in Schleswig on the bank of the River Eider on the German border stated that the Roman Empire ended at the Eider, the neighbouring people's "heiliges römisches Reich deutscher Nation". Especially in his strong campaign from around 1842 and until his death, Grundtvig regarded modern Germanism as the most detestable example of a cold and lifelessly disciplined systematization in the service of spiritual death. With a keen eye for the contrast between the German and the Danish mentality after the wretched peace treaty of 1864 , he wrote a poem in which he observed that all law and order in Germany was applied meticulously, "as in a paupers' burial ground, down to the last inch", whereas the Danes see life "as a garden of roses in full bloom, filled with mildness and laughter, a fountain of joy from which one may drink the cup of freedom «. This really puts the essential differences in a nutshell! ${ }^{14}$

In Grundtvig's concept of a good society and life on earth, the crux of the matter - as in the discursive form of teaching in the folk high school - is a vivacious interaction in the service of life. Grundtvig has described an ideal of this kind poetically in his philosophical poem $" \mathrm{~A}$ plain and cheerful, active life on earth", which in 1872 was extracted (with his permission) from a rhymed epistle already printed in 1842 as an appeal to his three teenage children, a kind of very early spiritual legacy to the next generation.

Whereas the leading spirits of Denmark's Golden Age mainly cultivated elitist art and a sophisticated way of life - one only needs to think of the Heibergs and an upstart like Andersen, who sought to ingratiate himself with the nobility and the royal family - Grundtvig defines his calm outlook without any form of affectation. Life should be "plain, cheerful and active", which is an excellent definition: an "enlightened" (in the sense of fully conscious) retracing of the footsteps of one's forebears, with a sense of responsibility towards history, with a 
uniformly dignified humanism regardless of station, be it high or low. The eye of man should be directed towards heaven, but at the same time "fully aware of everything beautiful and great on earth", for Grundtvig was no advocate of asceticism: according to God's creation, it is also an eye that can only be fully satisfied by the glory of eternity, life after death, for which it feels a longing. In its characteristically proverbial, substantival style, the poem virtually declares that in a human life of this kind the hand of the Creator is commensurate with nature's order.

For Grundtvig himself, his picture of life was unthinkable without emphasis on the Christian side of it. But in point of fact its elements can be detached from faith and still function, because - as the only intellectual figure of his period to do so - he delved deeply into the general pattern of nationalism. His form of enlightenment is directed towards what was a greater work of art than any of Thorvaldsen's famous statues or August Bournonville's ballets at the Royal Theatre in Copenhagen, namely a society that united the individual freedom of the citizen with true Christian charity. In his Handbook on World History (III, 1843) he draws attention (in connection with the Italian Renaissance) to what he regards as the right way of governing a state. It consists

in developing, while keeping the common good constantly in mind, a nation's capabilities towards the greatest and most beneficial forms of activity possible without wishing at any moment to provoke a clarity that is only of value when it emerges by itself, which it always will do whenever the activity is allowed to take its natural course; for then it must of necessity have a clear conception of itself, whereas all other so-called clarity is nought but empty delusion.

Grundtvig believed that the greatest art lay in "shaping a free and beautiful community of citizens, of living human beings", for it is far easier as a professional artist to handle words, tones, stone and colours beautifully. Grundtvig's conclusion was therefore that

while all the fine arts are wasted on an ugly life, a beautiful human life will embellish its surroundings and everything it touches of its own accord, so that the difference will be no more than that which exists between painted and naturally rosy cheeks, or between hothouse plants and those fruits and vegetables which, though they 
may ripen later, are much more succulent, robust, durable and appropriate to the season 'in free soil under an open sky'!'

The American anthropologist Steven M. Borish has testified to the fact that Grundtvig's thoughts have influenced Danish mentality and society. $\mathrm{He}$ attended three essentially different folk high schools (Kolding, Silkeborg and Askov) as a student and was also a guest lecturer at the University of Copenhagen. This resulted in 1991 in a book of 488 closely printed pages called The Land of the Living (taken from Grundtvig's famous poem of 1824 "De Levendes Land", which later became the poem "O Christendom"). As a scholar, Borish in principle describes Denmark and its inhabitants as if he were dealing with some far-off, exotic country and a strange culture. The cover has a line drawing of Grundtvig's mild countenance (P.C.Skovgaard's spiritual portrait from 1847) floating against the blue sky above a typical Danish farming landscape in the mellow colours of a late summer. In this way Borish conveys that for him, Denmark is saturated with the spirit of Grundtvigianism - whether it is aware of the fact or not and whether the Danes have read Grundtvig or not (most have not!). It is extremely entertaining and to a large extent instructive reading.

The book's subtitle is The Danish folk high schools and Denmark's non-violent path to modernization. It is clearly the non-violence, the absence of revolutions and civil upheavals, Danish delight in uniforms (combined with a wholehearted lack of respect for those who wear them), the 'cosy' atmosphere, willingness to talk things over and to compromise in political and social matters that strikes him as a model for the rest of the world. On the last page of his book Borish writes:

Few know of Grundtvig outside of Denmark, and the figure of Reventlow (whom one is tempted to call a Danish Tolstoy) is virtually unknown. Yet the alternative Danish modernization process to which they contributed included not one but a number of 'people-oriented' experiments and solutions: it is a topic of great potential interest to those concerned with third world development today. Similarly, the Danish philosophy of consistent non-violence and non-interference in the internal affairs of other nations could usefully be studied by citizens of larger nations.

He gives no indication, however, of how all this could be exported. 
Borish may be supplemented by a completely fresh reaction from the opposite side of the map. The Russian historian, Professor Julija Koudrin, who collaborated on a recently published history of Denmark in Russian, stated, in an interview she gave on 31 January 1997 to the Moscow correspondent of the Danish newspaper Politiken, that Grundtvig is the person she admires most in Denmark's past and present, and that the co-operative movement and the folk high schools are the most important developments in Denmark's history. Dr Koudrin finds that, for a Russian, the most important thing is to observe how Denmark has solved its political problems by parliamentary methods on the basis of an interaction between popular movements and the political apparatus. "You solve your differences by negotiation." If given the choice, she would prefer the Danish welfare model - according to which the State protects the individual citizen - to the American, which expects people to look after themselves. ${ }^{16}$

Two of Grundtvig's other ideas may also prove to be of interest outside Denmark in the next century. One of them concerns his firm belief - some might perhaps call it blind faith - in the power of the spoken word. In his view it was superior to writing. This was his "matchless" discovery in 1825: that Christ's oral introduction of baptism and communion are words received directly from God's mouth, to which the Bible must yield. This was naturally on the basis of Grundtvig's own endeavours as a preacher and Christian orator from his earliest youth, but in due course he also saw it confirmed in the secular and civil sphere by the positive response to his Mands Minde lectures and the continuation of his activities in the Danske Samfund. The reason was both Christian and national. In December 1839 Grundtvig wrote in his theological dissertation Kirkelige Oplysninger isar for lutherske Christne:

According to the Gospels, our Lord Jesus was not himself a writer, nor did he instruct his apostles to write, nor did he send them forth with a book from which they could obtain guidance, but "gracious words proceeded out of his mouth", and he promised them "a mouth and wisdom", which none could resist, and sent them from heaven "tongues like as of fire", just as he also orally gave them to understand what belonged to the Kingdom of God. ${ }^{17}$

In the above-mentioned long ecclesiastical poem Christenhedens Syvstjerne (1860), Grundtvig refers to "the ring of the spoken word in the 
mouths of the people" and "deep in their hearts" as an "echo of God's word". One of Grundtvig's favourite proverbs was " the [spoken] word moves (in the sense of 'circulates'), the written stands still (in the sense of 'is dead')". In his educational treatise Bøn og Begreb om en dansk Høiskole i Soer (Prayers and Ideas for a Danish High School in Sor $\varnothing$ ) (1840) he describes the human mouth as "the only living tool the spirit disposes of on earth ${ }^{18}{ }^{18}$ What he would have said to the living word as uttered by the media in the twentieth century is hard to imagine. Perhaps there is something in his ideas about the living word that should be incorporated in modern theories of the media.

The other idea is his high esteem for "womanliness". His distinction between the sexes, according to which the man represents reason and the woman emotion, was of course the usual Romantic idea. In Denmark it was effectively represented by the two finders of the golden horns in Oehlenschläger's famous poem from 1802: the yearning, dreaming woman, dancing along, and the man at his plough, toiling rationally. Grundtvig never became an emancipator of women in the more literal sense. For him, femininism was not a social and bourgeois concept about the life of the individual woman. Womanliness was a universally historic and all-embracing category. Denmark was for him a Kvind-Folk, which can mean both a "feminine people" or a "real woman", surrounded by awkward, belligerent Mand-Folk, which correspondingly can be taken to mean either "a he-man" or a "masculine people" (like the Swedes, the Norwegians and above all the Germans). It corresponded to the fact that another small nation with a glorious history, Ancient Greece, was obviously female.

As the woman represents love - and here it is fortunate that in Danish the same word can mean both erotic love and Christian charity the Danes are thus a "loving people", with deep yearnings rather than vainglorious achievements to blind the world. The yearnings concern both the national past and the Christian faith. Grundtvig can endow Denmark with various symbolic roles, including that of the widow from Nain whose dead son Jesus brought back to life, Freyja the Old Norse goddess of love who wept tears of gold while yearning for her vanished husband and - more warlike - the Schleswig virgin Hede, who according to Saxo fought for the Danish cause at the Battle of Bravalla. To this must be added Grundtvig's whole concept of the Danish language as being especially the province of mothers and girls. 
Doubt can of course be cast on the notion that the Danes should regard their past with particularly great love - as did the conservative historian Johannes Steenstrup, declaring that "here we are beyond the bounds of all scientific and logical concepts.${ }^{19}$ Many people today would also feel embarrassed by Grundtvig's undaunted reference to the Danes in modern times as being God's chosen people, a parallel to the Jews in the Old Testament, and his repeated emphasis of the Danes' love and/or charity.

Yet there is a grain of truth in the idea that Danish society is characterized by a certain motherliness and womanliness. The German (but Danish-employed) media researcher Henning Eichberg thus finds that Denmark's TV and press are open to gentle, feminine news items that would stand little chance in the German media (which no doubt to some degree or other may be assumed to satisfy the expectations of their public). One may compare this with the general lack of understanding normally displayed by the Danes for violence and brutality as instruments of self-assertion. And then one feels it might be a good thing if this - in Grundtvig's eyes - specifically womanly and loving attitude would spread to other, larger countries.

\section{Interaction across all borders}

Was Grundtvig at all keen on being taken up abroad, or did he regard Denmark as the centre of modem intellectual history? On one occasion he certainly did regard his view of history as worthy of being exported. This was in 1863 when the new independent kingdom of Greece chose a Danish prince as its king instead of the previous Bavarian-born monarch. This confirmed in Grundtvig's view (in the little 1869 supplement to the third volume of his history of the world) that Denmark was to arouse the Greek people from the mortal sleep to which it had succumbed since antiquity. The Danes were to do so - he wrote by teaching the Greeks the true Christian faith and baptism to replace the no longer valid, feeble forms patched together in the past by the Greek Orthodox Church. ${ }^{20} \mathrm{He}$ was undoubtedly alluding to himself as the person who would be able to help the Greeks towards a better concept of baptism.

Grundtvig himself had derived benefit from historical, cultural and social interactions. Compared with most of his contemporaries, he 
travelled further in time in the course of his reading than physically in space. On the other hand England, the only foreign country he visited several times and for protracted periods, exercised a decisive influence upon him. Amongst the things he observed and noted in London was the open, oral form of debate in the House of Commons and the open procedures in the law courts, both of which served to create a lively intellectual climate. Seen in a longer perspective, however, these customs could be part of what the Vikings, that is to say the Danes and other Scandinavians, originally brought to England. The practical part of Grundtvig's folk high school ideas include borrowings from his positive impression of college life at the famous old English universities but may perhaps today, in a 'Danified' form, be returned to the English-speaking countries and also to the former British colonies in the Third World.

Both Grundtvig's theology and his attitude to nationalism, especially with regard to language, stem from Germans (Luther, Herder and Fichte) but already in the nineteenth century could apparently be returned to Germany bearing Grundtvig's special Danish stamp.

This could engender optimism, also with regard to Grundtvig's future possibilities of contributing to a sensible development in international culture. It might well develop according to his own motto: "Late but sweet! «1 * $^{*}$

Translated from the Danish

by David Hohnen

* The above article was originally given as a lecture in Danish (in a shorter form) on 7 October 1996 as one in a public series entitled "Topical Research: Danish Contributions to World Culture " arranged by the Royal Danish Society of Sciences and Letters. It assembles and passes on a number of results from Grundtvig research that have not been included in full detail in the references given in the notes. 


\section{Notes}

1 Grundtvigs Sang-Vark, IV, Copenhagen 1949, no. 161.

2 Danmarks gamle Folkeviser no. 7. Didrik is identical with Theodoric the Ostrogoth.

3 As a result of general debility and failing eyesight, Grundtvig's handwriting here is so difficult to read that the poem can only be partially interpreted with a degree of certainty.

4 In 1824 Grundtvig was specifically aiming, firstly, at the Copenhagen newspaper Nyt Aftenblad (The New Evening Paper) in which the former friend of his youth, C. Molbech, had harshly criticized Ingemann's national epic Waldemar den Store (Valdemar the Great), and secondly at his older cousin, the philosopher Henrik Steffens, who had emigrated. During a visit to Copenhagen and under the influence of the prominent Danish poet Adam Oehlenschläger and his circle, Steffens had treated Grundtvig shabbily (cf. Grundtvig og Ingemann. Brevvexling 1821-1859, Copenhagen 1882, p. 37). It may also have been an attack on the complete indifference displayed in Danish literary circles towards Grundtvig's long prophetic-cum-confessional poem NyaarsMorgen (New Year's Morning) on its publication in August.

5 Hans Brix, Analyser og Problemer, IV, Copenhagen 1938, p. 81.

6 This passage is based particularly on Theodor Jørgensen, "Grundtvigs økumeniske helligsåndsteologi" in Henning Thomsen (ed.), Du som går ud fra den levende Gud. Bibelteologiske og teologihistoriske overvejelser over Helligånden, Copenhagen 1993, pp. 70-84.

7 Grundtvigs Sang-Vark, I, Copenhagen 1949, no. 397.

8 Grundtvig's distant relative, the poet and clergyman Steen Steensen Blicher (1782-1848) had already in 1839 encouraged in vain the introduction of a form of national Olympic Games on Himmelbjerget (Sky Mountain) in Jutland which were to include intellectual, artistic and physical contests. It would appear that Grundtvig had little sympathy for the idea. Despite personal invitations he declined to participate in any of the Himmelbjerg meetings held in increasingly modest forms during the years between 1839 and 1844. Despite the fact that in 1844 Grundtvig was convalescing after an attack of manicdepressive psychosis, he still had sufficient energy on 4 July to make a speech at the meeting held at Skamlingsbanken, 78 kilometres south of Himmelbjerget. Sporting activities were not introduced at folk high schools until 1884 (at 
Vallekilde) and then only as gymnastics of the kind prescribed by the Swedish Romantic poet and natural scientist P.H. Ling, in which he placed emphasis on team discipline and floor exercises intended to cultivate a beautiful physique.

9 The following passage is based especially on Holger Bernt Hansen, "Grundtvig and the Third World. The Transfer of Grundtvig's Ideas to Other Peoples and Cultures", in A.M. Allchin et al. (eds.), Heritage and Prophecy. Grundtvig and the English-speaking World, Aarhus 1993, pp. 299-322.

10 Flemming Lundgreen-Nielsen, "Grundtvig og danskhed", in Dansk Identitetshistorie, III, Copenhagen 1992, pp. 9-187, with an English summary in vol. IV, 1992, pp. 553-54, gives a closer account of this.

11 In his book Die Politik des Einzelnen. Studien zur Genese der skandinavischen Ziviltheologie. Ludvig Holberg, Sфren Kierkegaard, N.F.S. Grundtvig, Göttingen 1977, the German sociologist Berndt Henningsen uses the term 'civil theology' to cover Grundtvig's secular social ideas.

12 The importance of Grundtvig's visits to England has been particularly emphasized, documented and confirmed in Kaj Thaning's dissertation Menneske først-Grundtvigs opgør med sig selv, Copenhagen 1963.

13 The quotations are from K.E.Bugge (ed.), Grundtvigs skoleverden i tekster og udkast, II, Copenhagen 1968, p. 212, and Grundtvig's periodical Danskeren of 2 March 1850, III, p. 127.

14 Kierkegaard spent part of his life fighting in a similar fashion the system expounded by the German philosopher Hegel, which was self-contained and complete but omitted to leave room for individual reflection. Incidentally, one of Grundtvig's favourite poets from his earliest reading years, Jens Baggesen, in his travel book Labyrinten (1792-93), had already pronounced the symmetrically laid-out electoral fortress town of Mannheim in Baden to be a slave-based institution of death with a geometrical street grid and identical houses. As a counterweight to this kind of German coercion Baggesen advocated everything that is living, warm, loving - a flame, a stream, an embrace: "Life is round and Death is angular."

15 Holger Begtrup (ed.), Grundtvigs Udvalgte Skrifter, VII, Copenhagen 1908, p. $487 \mathrm{f}$.

16 Interview with Henrik Kaufholz in Politiken, 31 January 1997. 
17 Holger Begtrup (ed.), Grundtvigs Udvalgte Skrifter, VIII, Copenhagen 1909, p. 393. In his notes Grundtvig himself refers to Luke 4 and 11 and Acts 1; the last reference should be Acts 2:3. Grundtvig also quotes from Luke 21:15.

K.E. Bugge (ed.), Grundtvigs skoleverden i tekster og udkast, II, Copenhagen 1968 , p. 184.

Johannes Steenstrup, Historieskrivningen i Danmark i det 19. Aarhundrede (1801-1863), Copenhagen 1889, p. 67.

Holger Begtrup (ed.), Grundtvig's Udvalgte Skrifter, VII, Copenhagen 1908, p. 702.

21 The expression was not coined by Grundtvig but is a quotation of the title of a narrative poem by T.C.Bruun in the latter's collection Rimerier, Copenhagen 1788. Around 1800 Grundtvig was greatly impressed by this disrespectful Voltairean mocking-bird. On the other hand he tried in 1812 - in vain - to have an embargo placed on Bruun's collected works on the strength of the blasphemy paragraph in the printing decree of 1799. Later he appropriated the phrase, but incontestably gave it a nobler content than Bruun. 